\title{
Overexpression of long noncoding RNA HOTTIP promotes tumor invasion and predicts poor prognosis in gastric cancer
}

This article was published in the following Dove Press journal:

OncoTargets and Therapy

7 April 2016

Number of times this article has been viewed

\author{
Heng Ye' \\ Kun Liu ${ }^{2}$ \\ Keqing Qian' \\ 'Department of Oncology, \\ ${ }^{2}$ Department of General Surgery, \\ The Affiliated Hospital of Nanjing \\ Medical University, Changzhou No 2 \\ People's Hospital, Changzhou, Jiangsu, \\ People's Republic of China
}

Purpose: Long noncoding RNAs have been proved to play important roles in the tumorigenesis and development of human gastric cancer (GC). Our study aims to investigate the expression and function of Homeobox A transcript at the distal tip (HOTTIP) in GC.

Methods: HOTTIP expression was detected in GC tissues and cell lines by using quantitative reverse transcription polymerase chain reaction. Association between HOTTIP levels and clinicopathological factors and patient prognosis was also analyzed. MTT, flow cytometry, and transwell invasion and migration assays were used to investigate the role of HOTTIP in the regulation of biological behaviors of GC cells.

Results: HOTTIP expression was remarkably increased in GC tissues and cell lines compared with that in the normal control. Clinicopathologic analysis revealed that high HOTTIP expression correlated with larger tumor size, deeper invasion depth, positive lymph node metastasis, advanced TNM stage, and shorter overall survival. Multivariate regression analysis identified HOTTIP overexpression as an independent unfavorable prognostic factor in GC patients. Moreover, HOTTIP downregulation by si-HOTTIP transfection impaired GC cell proliferation, promoted cell apoptosis, and reduced cell invasion and migration.

Conclusion: These findings suggested that HOTTIP may contribute to GC initiation and progression, and would be not only a novel prognostic marker but also a potential therapeutic target for this disease.

Keywords: long noncoding RNA, HOTTIP, gastric cancer, prognosis

\section{Introduction}

Gastric cancer (GC) is the fourth most prevalent human malignancy and the second leading cause of cancer deaths worldwide. ${ }^{1}$ The majority of GC patients are diagnosed at advanced stage due to vague initial symptoms. ${ }^{2}$ Despite recent advances in surgical techniques, new chemotherapy regimens, radiotherapy, and molecular-targeted therapy, the clinical outcome of GC patients remains dismal, with a 5-year survival rate of $25 \%$ or less. ${ }^{3}$ Previous studies have reported many oncogenes and tumor suppressor genes closely associated with $\mathrm{GC}^{4-6}$ but the highly complex molecular mechanisms underlying its carcinogenesis and progression are still obscure. Therefore, it is urgent to identify reliable biomarkers of GC for its early diagnosis, effective therapy, and prognosis evaluation.

Long noncoding RNA (lncRNA), >200 nucleotides in length, is a type of noncoding RNA molecule that can regulate gene expression in transcriptional or post-transcriptional level. ${ }^{7,8}$ Recent research has shown that lncRNAs participate in a large number of cellular processes, such as cell proliferation, differentiation, apoptosis, and cell cycle progression. ${ }^{9}$ Emerging evidence indicates that lncRNAs play important roles in the biology of
Department of Oncology, The Affiliated Hospital of Nanjing Medical University, Changzhou No 2 People's Hospital, 213000 Changzhou, Jiangsu, People's Republic of China

Email docqiankeq@163.com 
human cancers, which may provide a new but promising way to deal with cancer. ${ }^{10}$ Functional lncRNAs may be applied for cancer diagnosis and prognosis, and also act as potential novel therapeutic targets. For example, increased expression of lncRNA BRAF activated non-coding RNA (BANCR) confers poor prognosis in patients suffering from malignant melanoma and retinoblastoma. ${ }^{11,12} \operatorname{lncRNA}$ Hox transcript antisense intergenic RNA (HOTAIR) is a negative prognostic factor for osteosarcoma, lung cancer, and colorectal cancer. ${ }^{13-15}$ lncRNA very-low-density lipoprotein receptor (VLDLR), Plasmacytoma variant translocation 1 (PVT1) and growth arrest-specific transcript 5 (GAS5) could regulate tumor cell responses to chemotherapy. ${ }^{16-18}$ However, the understanding of the expression and function of lncRNAs in GC is still in the early stage.

Homeobox A (HOXA) transcript at the distal tip (HOTTIP) is a recently functionally characterized lncRNA located at the $5^{\prime}$ end of the HOXA cluster. ${ }^{19}$ Increased HOTTIP expression has been reported in tongue squamous cell carcinoma, ${ }^{20}$ lung cancer, ${ }^{21}$ pancreatic cancer, ${ }^{22}$ and hepatocellular carcinoma. ${ }^{23}$ In these tumors, HOTTIP may serve as a potential oncogene, and HOTTIP overexpression was associated with enhanced cell proliferation, reduced apoptosis, and increased cell migration. However, no report of HOTTIP in GC has been found. In the present study, we examined HOTTIP expression in GC tissues and cell lines. We also investigated the correlation between HOTTIP levels and clinicopathological characteristics and overall survival of GC patients. Moreover, we explored the role of HOTTIP in the regulation of biological behaviors of GC cells.

\section{Materials and methods}

\section{Patients and clinical specimens}

Fresh primary GC tumor tissues and matched NATs $(\geq 3 \mathrm{~cm}$ away from tumor margin) were collected from 98 pathologically confirmed GC patients in Changzhou No 2 Hospital between January 2009 and May 2010. All samples were frozen immediately in liquid nitrogen and stored at $-80^{\circ} \mathrm{C}$ until analysis. Patients with two or more different malignancies were excluded. None of the patients had received preoperative radiotherapy or chemotherapy. Patient characteristics are shown in Table 1. Follow-up data were available for all patients. Overall survival was defined as the amount of time from the day of primary surgery to the date of death or the end of follow-up (for living patients). The ethical committees of Changzhou No. 2 Hospital affiliated to Nanjing Medical University approved this study, and written informed consent was obtained from all patients.
Table I Correlation between HOTTIP expression and different clinicopathological features in patients with gastric cancer

\begin{tabular}{|c|c|c|c|}
\hline Characteristics & $\begin{array}{l}\text { High HOTTIP } \\
\text { expression (\%) }\end{array}$ & $\begin{array}{l}\text { Low HOTTIP } \\
\text { expression (\%) }\end{array}$ & $P$-value \\
\hline \multicolumn{4}{|l|}{ Age (years) } \\
\hline$\geq 60$ & $34(47.9)$ & $37(52.1)$ & 0.652 \\
\hline$<60$ & I5 (55.6) & $12(44.4)$ & \\
\hline \multicolumn{4}{|l|}{ Sex } \\
\hline Male & $26(46.4)$ & $30(53.6)$ & $0.54 I$ \\
\hline Female & $23(54.8)$ & $19(45.2)$ & \\
\hline \multicolumn{4}{|l|}{ Differentiation } \\
\hline Well-moderate & $12(40.0)$ & $18(60.0)$ & 0.273 \\
\hline Poor & $37(54.4)$ & $31(45.6)$ & \\
\hline \multicolumn{4}{|l|}{ Lauren type } \\
\hline Intestinal & $27(43.5)$ & $35(56.5)$ & 0.142 \\
\hline Diffuse and mixed & $22(6 I . I)$ & 14 (38.9) & \\
\hline \multicolumn{4}{|l|}{ Tumor size } \\
\hline$\geq 5 \mathrm{~cm}$ & $36(61.0)$ & $23(39.0)$ & 0.006 \\
\hline$<5 \mathrm{~cm}$ & $13(33.3)$ & $26(66.7)$ & \\
\hline \multicolumn{4}{|l|}{ Invasion depth } \\
\hline TI, T2 & $14(36.8)$ & $24(63.2)$ & 0.031 \\
\hline T3, T4 & $35(58.3)$ & $25(4 I .7)$ & \\
\hline \multicolumn{4}{|l|}{ TNM stage } \\
\hline I/II & II (33.3) & $22(66.7)$ & 0.013 \\
\hline III & $38(58.5)$ & $27(4 \mid .5)$ & \\
\hline \multicolumn{4}{|l|}{ Lymphatic metastasis } \\
\hline Negative & $10(33.3)$ & $20(66.7)$ & 0.028 \\
\hline Positive & 39 (57.4) & $29(42.6)$ & \\
\hline
\end{tabular}

Abbreviation: HOTTIP, HOXA transcript at the distal tip.

\section{Cell culture and RNA interference}

Human GC cell lines (AGS, SGC-7901, BGC-823, and MKN-28) and human normal gastric epithelial cell line GES-1 were obtained from the Institute of Biochemistry and Cell Biology of the Chinese Academy of Sciences (Shanghai, People's Republic of China). The cells were maintained in Roswell Park Memorial Institute 1640 supplemented with $10 \%$ heat-inactivated fetal bovine serum, $100 \mathrm{U} / \mathrm{mL}$ of penicillin, and $100 \mu \mathrm{g} / \mathrm{mL}$ streptomycin sulfate. Cultures were incubated in a humidified atmosphere of $5 \% \mathrm{CO}_{2}$ at $37^{\circ} \mathrm{C}$.

lncRNA HOTTIP small interfering RNA (si-HOTTIP) and nontargeting siRNA (si-NC) were purchased from Sigma-Aldrich (St Louis, MO, USA). GC cells were transfected with siRNA by using Lipofectamine 2000 (Invitrogen, Carlsbad, CA, USA) according to the manufacturer's instructions. The cells were harvested for further assays 48 hours after transfection.

\section{RNA extraction, reverse transcription, and quantitative reverse transcription polymerase chain reaction}

Total RNA was extracted using the Trizol reagent (Invitrogen) according to the manufacturer's instructions. RNA was reverse 
transcribed into cDNA using a Reverse Transcription Kit (Takara, Dalian, People's Republic of China). HOTTIP expression levels were measured with quantitative reverse transcription polymerase chain reaction (qRT-PCR) using an ABI7500 system and the SYBR Green PCR Master Mix (Takara). GAPDH was used as an internal control. The primer sequences for HOTTIP were 5'-GTGGGGCCCAGACCCGC-3' (forward) and 5'-AATGATAGGGACACATCGGGGAACT-3' (reverse). Each assay was performed in triplicate, and relative HOTTIP expression was normalized to GAPDH using the $2^{-\Delta \mathrm{Ct}}$ method. The fold change of HOTTIP in GC relative to the matched NAT was determined by the $2^{-\Delta \Delta \mathrm{Ct}}$ method, where $\Delta \Delta$ cycle threshold $(\mathrm{CT})=\left(\mathrm{CT}_{\text {HOTTIP }}-\mathrm{CT}_{\mathrm{GAPDH}}\right)$ (in $\mathrm{GC}$ samples $)-\left(\mathrm{CT}_{\text {HOTTIP }}-\mathrm{CT}_{\mathrm{GAPDH}}\right)$ (in NATs).

\section{Cell proliferation assay}

Cell proliferation was analyzed using MTT assay. Briefly, $\sim 1 \times 10^{3}$ cells were seeded into a 96-well plate and incubated for 1, 2, 3, and 4 days. At the indicated time point, 20 $\mu \mathrm{L}$ of MTT ( $5 \mathrm{mg} / \mathrm{mL}$ ) (Sigma-Aldrich) was added into each well and incubated for another 4 hours. Then the supernatants were removed and $150 \mu \mathrm{L}$ of DMSO (Sigma-Aldrich) was added to terminate the reaction. The absorbance value (optical density [OD]) was measured at $490 \mathrm{~nm}$ on a microplate reader (Molecular Devices, Sunnyvale, CA, USA).

\section{Detection of apoptosis by flow cytometry}

Forty-eight hours after transfection, the GC cells were harvested, washed, and resuspended in ice-cold phosphatebuffered saline. The cells were then treated with propidium iodide (10 $\mu \mathrm{g} / \mathrm{mL}$; Sigma-Aldrich) and Annexin V-FITC (50 $\mu \mathrm{g} / \mathrm{mL}$, BD Biosciences, San Jose, CA, USA) in the dark for 15 minutes at room temperature, and examined by flow cytometry (FACScan; BD Biosciences).

\section{Cell invasion and migration assays}

Cell migration and invasion assays were performed using transwell chambers ( $8 \mu \mathrm{m}$ pore size; BD Biosciences). For the migration assay, approximately $1 \times 10^{5} \mathrm{GC}$ cells in serumfree media were seeded into the upper chambers after siRNA transfection. The lower chamber contained medium with $20 \%$ fetal bovine serum as a chemoattractant. Following a 48-hour incubation, the cells located on the lower surface of the chamber were stained and counted using a microscope (Olympus Corp., Tokyo, Japan). The invasion assay protocol was similar to the migration assay except that the upper chambers were first covered with Matrigel.

\section{Statistics}

All statistical analyses were performed using the SPSS 17.0 software package (SPSS, Chicago, IL, USA). The significance of differences between groups was estimated by Student's $t$-test and chi-square test. Survival curves were constructed with the Kaplan-Meier method and compared by log-rank test. The significance of survival variables was evaluated using a multivariate Cox proportional hazards regression analysis. $P<0.05$ was considered statistically significant.

\section{Results}

Increased HOTTIP expression in GC tissues and cell lines

HOTTIP expression in GC tissues and cell lines was measured by qRT-PCR. Figure $1 \mathrm{~A}$ and $\mathrm{B}$ showed a significant high expression of HOTTIP in GC tissues compared with NATs $(P<0.05)$. HOTTIP expression was also significantly increased in four GC cell lines compared to normal gastric epithelial cell GES-1 (Figure 1C, $P<0.05$ ). Since SGC-7901 and MKN-28 exhibited relative high HOTTIP expression among all tested cell lines, these two cell lines were chosen for the subsequent in vitro experiments.

\section{Correlation between HOTTIP expression and clinical features}

We further analyzed the association between HOTTIP expression levels and clinicopathological characteristics of GC. GC samples were classified into HOTTIP low expression group $(n=49)$ and HOTTIP high expression group $(n=49)$ according to the median HOTTIP expression level of all GC samples. The association between clinicopathological characteristics and HOTTIP expression is summarized in Table 1. We found that HOTTIP level was associated with tumor size, tumor depth, lymph node metastasis, and clinical stage. However, we did not find any significant correlation between HOTTIP levels and other clinicopathological features, such as patient's sex, age, Lauren type, and cancer differentiation.

\section{Prognostic values of HOTTIP expression in GC}

We further evaluated the associations of HOTTIP expression level with survival of GC patients. Survival analysis indicated that patients in low HOTTIP expression group had better 5 -year overall survival than those in high HOTTIP expression group $(P<0.001$, Figure 2$)$. Univariate analysis revealed that HOTTIP expression, tumor size, tumor depth, lymphatic invasion, and TNM stage were prognostic factors for patient's 
A

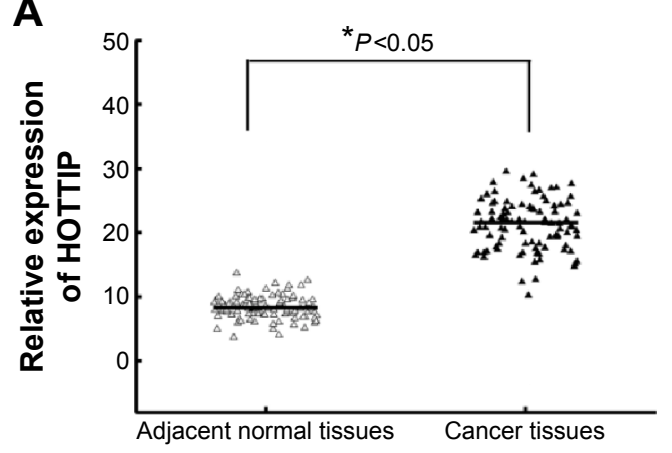

B

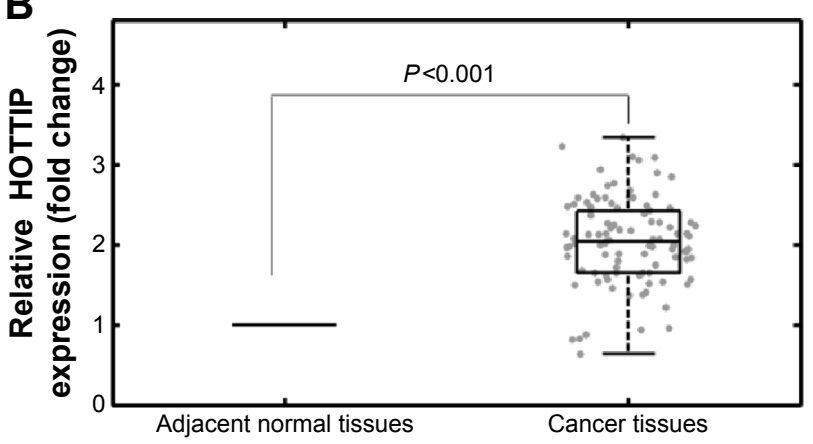

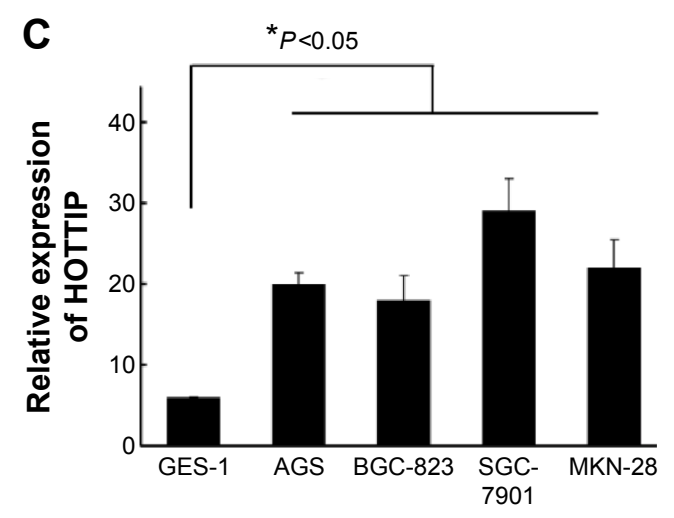

Figure I Relative HOTTIP expression levels in gastric cancer tissues and cell lines.

Notes: (A) HOTTIP expression was significantly higher in gastric cancer tissues than in the corresponding NATs. HOTTIP levels were calculated by the $2^{-\Delta C t}$ method and normalized to GAPDH. (B) The fold change of HOTTIP in GC relative to the matched NAT in 98 GC patients. (C) Increased HOTTIP expression in four GC cell lines compared to normal gastric epithelial cell line GES-I. $* P<0.05$.

Abbreviations: GC, gastric cancer; HOTTIP, HOXA transcript at the distal tip; NAT, normal adjacent tissue.

prognosis (Table 2). Multivariate analysis confirmed high HOTTIP expression $(P=0.015$, relative risk $[R R]=2.54)$ as an unfavorable prognostic factor for GC patients independent of other clinicopathological factors, including depth of infiltration $(P=0.003$, hazard ratio $[\mathrm{HR}]=3.15)$, lymph node status $(P=0.012, \mathrm{HR}=2.76)$, and TNM stage $(P=0.008$, $\mathrm{HR}=2.92$; Table 2).

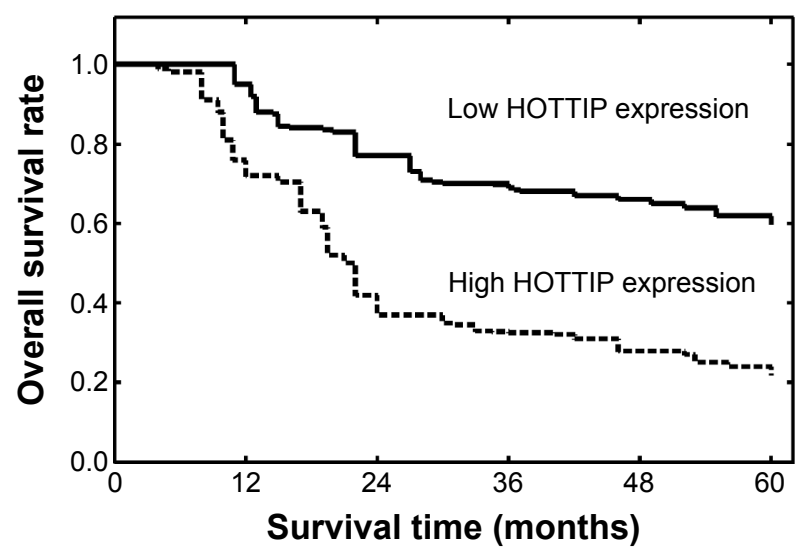

Figure 2 Kaplan-Meier survival curves of gastric cancer patients based on HOTTIP expression status.

Note: Patients in the high HOTTIP expression group had significantly poorer prognosis than those in low HOTTIP expression group $(P<0.00$ I, log-rank test). Abbreviation: HOTTIP, HOXA transcript at the distal tip.

\section{Effects of HOTTIP downregulation on the biological behaviors of SGC-790I and MKN-28 cells}

Finally, we explored the role of HOTTIP in regulating the biological behaviors of GC cells. HOTTIP expression in SGC-7901 and MKN-28 cells was evidently downregulated after si-HOTTIP transfection (Figure 3A). As shown in Figure 3B and C, HOTTIP downregulation impaired GC cell

Table 2 Univariate and multivariate analysis of overall survival in 98 gastric cancer patients

\begin{tabular}{|c|c|c|c|c|}
\hline \multirow[t]{2}{*}{ Variables } & \multicolumn{2}{|c|}{$\begin{array}{l}\text { Univariate } \\
\text { analysis }\end{array}$} & \multicolumn{2}{|c|}{$\begin{array}{l}\text { Multivariate } \\
\text { analysis }\end{array}$} \\
\hline & $\mathbf{R} \mathbf{R}$ & $P$-value & $\mathbf{R R}$ & $P$-value \\
\hline Age (years) & 0.94 & 0.225 & 1.44 & 0.095 \\
\hline Sex & 1.41 & 0.136 & 0.98 & 0.272 \\
\hline Differentiation & 1.55 & 0.094 & 1.58 & 0.074 \\
\hline Lauren type & 1.33 & 0.142 & 1.16 & 0.214 \\
\hline Tumor size & 3.09 & 0.006 & 1.53 & 0.082 \\
\hline Invasion depth & 2.85 & 0.015 & 3.15 & 0.003 \\
\hline Lymphatic metastasis & 2.57 & 0.028 & 2.76 & 0.012 \\
\hline TNM stage & 3.94 & $<0.001$ & 2.92 & 0.008 \\
\hline HOTTIP expression & 3.78 & $<0.001$ & 2.54 & 0.015 \\
\hline
\end{tabular}

Abbreviations: HOTTIP, HOXA transcript at the distal tip; RR, relative risk. 
proliferation and promoted cell apoptosis compared to the si-NC group. In addition, we observed reduced cell invasion/ migration in SGC-7901 and MKN-28 cells after si-HOTTIP transfection (Figure 3D and E).

\section{Discussion}

Identifying novel molecules that take part in GC formation and progression may be helpful for improving the diagnosis, prevention, and treatment of this disease. The relationship between IncRNAs and tumors has currently become one of the focuses of cancer studies. Abnormal expressions of several lncRNAs have been reported in GC. For example, overexpression of IncRNA H19 promoted the features of GC including proliferation, migration, invasion, and metastasis. ${ }^{24}$ Plasma H19 could serve as a potential biomarker for diagnosis of $\mathrm{GC}$, in particular for early tumor screening. ${ }^{25}$ Li et $\mathrm{al}^{26}$ found that high expression of IncRNA BANCR was positively associated with clinical stage, tumor depth, lymph

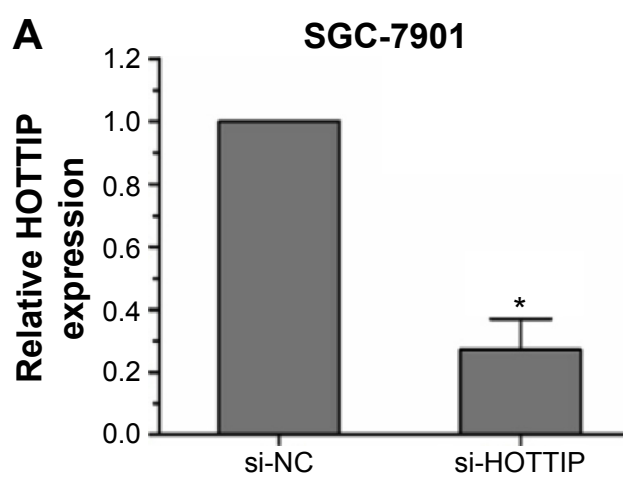

B

SGC-7901
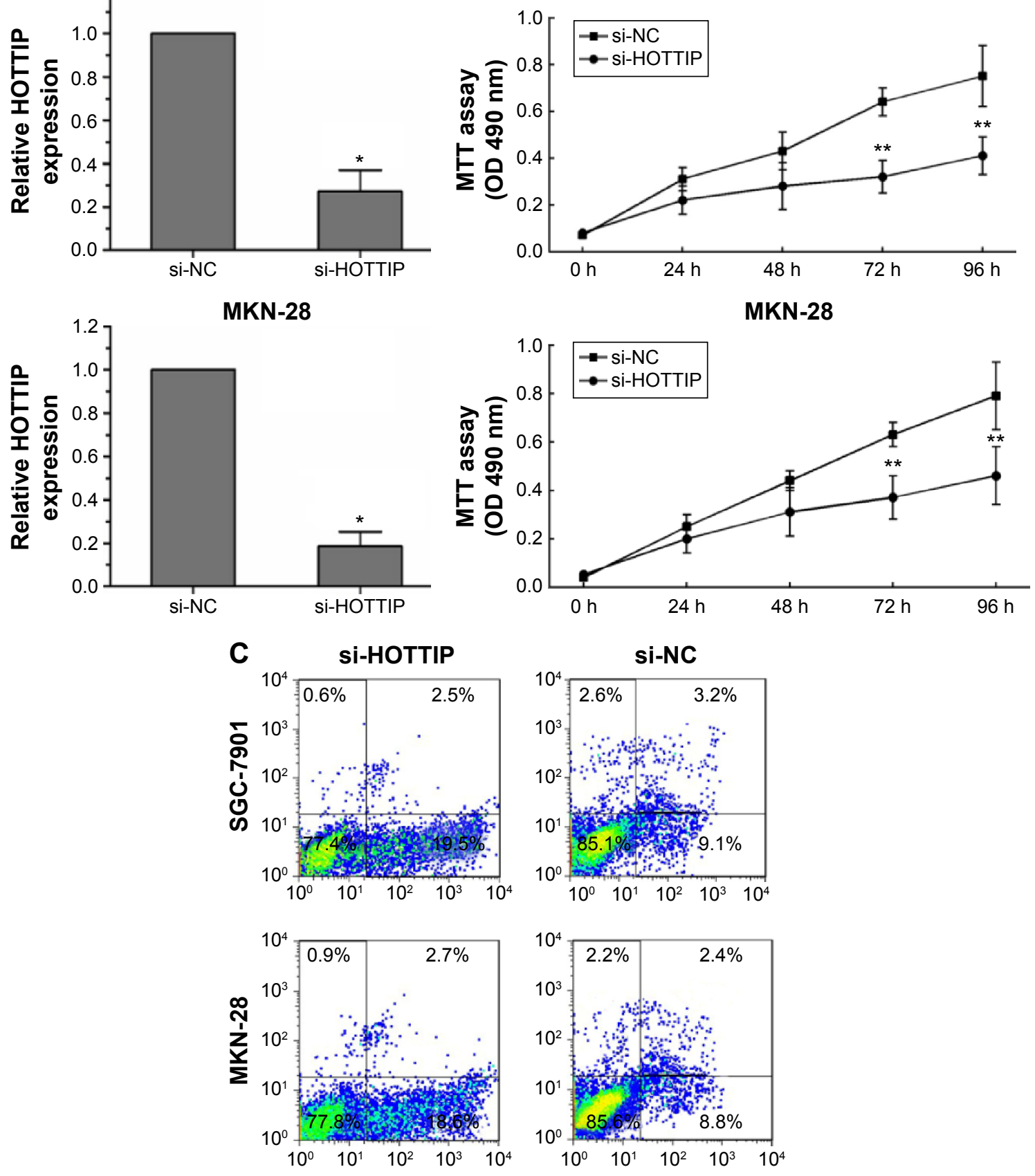

Figure 3 (Continued) 

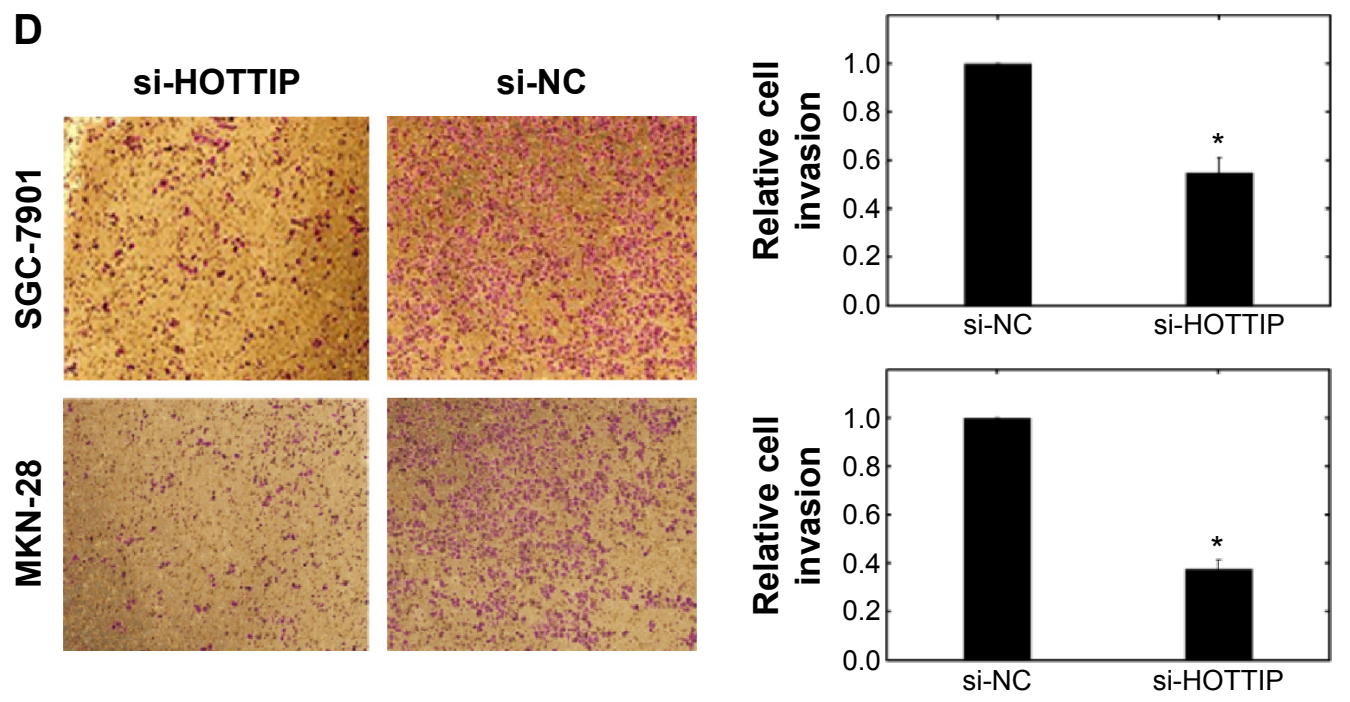

$\mathbf{E}$
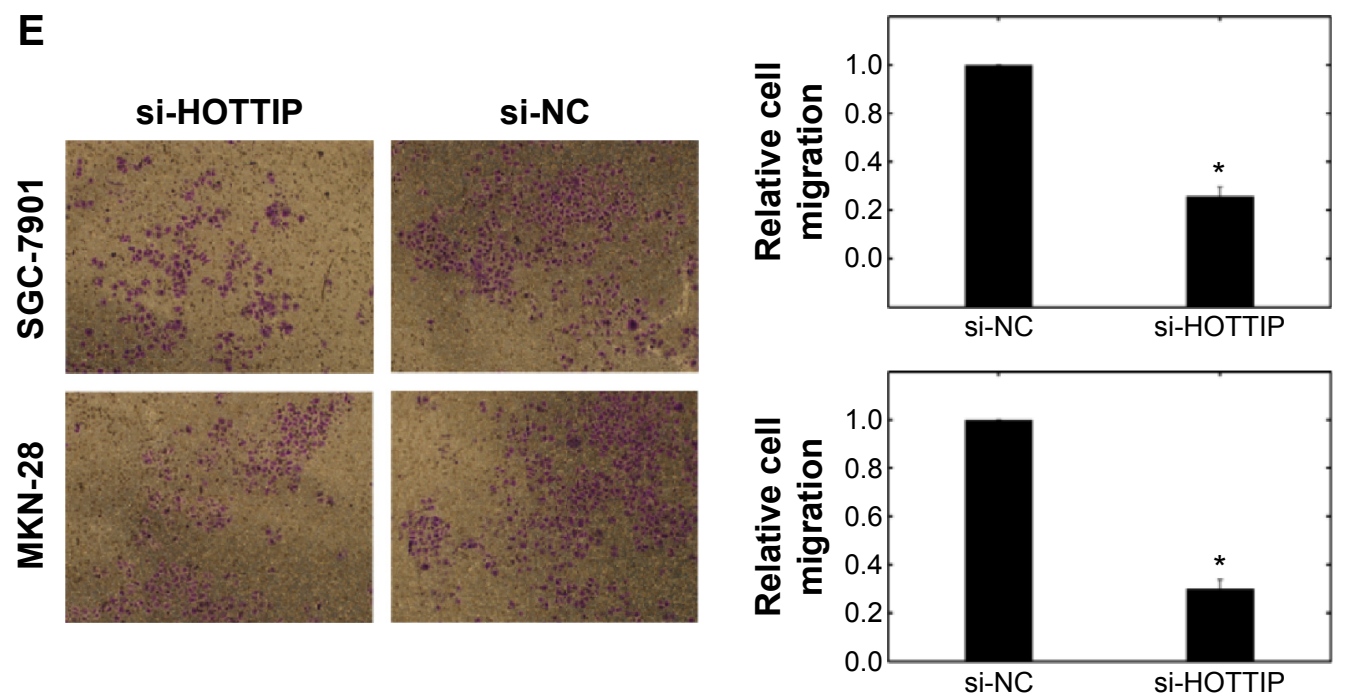

Figure 3 Effects of HOTTIP on the biological behaviors of SGC-790I and MKN-28 cells.

Notes: (A) Expression of HOTTIP was significantly downregulated after si-HOTTIP transfection. *P $<0.05$. (B) Cell proliferation was measured by MTT assays in SGC-790 I and MKN-28 cells transfected with si-HOTTIP or si-NC. $* * P<0.01$. (C) Flow cytometric analysis showed induced cell apoptosis after si-HOTTIP transfection. (D, E) The transwell invasion and migration assays showed that the number of invaded or migrated cells was significantly lower in the si-HOTTIP-transfected group than in the si-NCtransfected group. $* P<0.05$.

Abbreviations: HOTTIP, HOXA transcript at the distal tip; h, hour; si-HOTTIP, HOTTIP small interfering RNA; si-NC, nontargeting small interfering RNA; OD, optical density.

node metastasis, and distant metastasis in GC patients. They also confirmed high expression of BANCR as an independent unfavorable prognostic factor in GC patients. Zhang et $\mathrm{al}^{27}$ demonstrated that knockdown of lncRNA PVT1 could reverse the cisplatin resistance in cisplatin-resistant $\mathrm{GC}$ cell lines, while upregulation of PVT1 significantly reduced GC cell apoptosis and inhibited the sensitivity of GC cells to anticancer drugs. These findings suggested that lncRNAs might play important roles in GC initiation and development, and have a great potential for clinical application.

In the present study, we first investigated HOTTIP expression in GC tissues and cell lines by RT-PCR. We observed high HOTTIP expression in GC specimens compared to NATs. Additionally, HOTTIP expression was markedly increased in GC cell lines compared with normal gastric epithelium cells. Our results provided the first evidence that high HOTTIP expression was closely associated with GC carcinogenesis. Then we correlated HOTTIP levels with different clinicopathological factors of GC tissues. We found that high HOTTIP expression was more frequently detected in GC patients with larger tumor size, deeper invasion depth, positive lymph node metastasis, and advanced TNM stage. Downregulation of HOTTIP in GC cells would reduce cell proliferation, enhance cell apoptosis, and impair cell invasion. These findings revealed that HOTTIP might be involved in GC progression and contribute to 
molecular-targeted therapy. Finally, our research showed that GC patients with high HOTTIP levels tended to have shorter overall survival than patients with lower levels. Multivariate Cox hazard regression analysis identified high HOTTIP expression as an independent indicator of unfavorable prognosis. To our knowledge, this is the first study to analyze the expression and clinical significance of HOTTIP in GC.

Our results were consistent with the previous findings in other cancers. In lung cancer A549 cells, cell proliferation and colony formation were significantly inhibited in vitro after successfully depletion of HOTTIP. ${ }^{21}$ Tumor growth in vivo was also suppressed in a mouse model. Moreover, depletion of HOTTIP caused cell cycle arrest in G0/G1 phase and induced significant cell apoptosis. In pancreatic cancer, knockdown of HOTTIP inhibited tumor cell proliferation, promoted apoptosis, and reduced migration. ${ }^{28}$ Additionally, inhibition of HOTTIP potentiated the antitumor effects of gemcitabine in vitro and in vivo. ${ }^{22}$ In tongue squamous cell carcinoma, high HOTTIP expression positively correlated with depth of infiltration (T stage), clinical stage, and distant metastasis and predicted poor survival. ${ }^{20}$ High HOTTIP expression was also associated with increased metastasis formation and decreased overall survival in patients with hepatocellular carcinoma. ${ }^{29}$ Taken together, these researches indicated that HOTTIP might serve as an oncogene in several types of human cancers. However, the complex molecular mechanisms underlying high HOTTIP expression in human cancers and its function are still incompletely known. More studies should be applied to clarify the precise mechanisms by which HOTTIP contributes to tumor formation and progression.

We are aware of some limitations in our work. First, the clinical part was a retrospective study, and the tumor sample size was relatively small. Second, we observed the effects of HOTTIP on the proliferation, apoptosis, invasion, and migration of GC cells, but its association with colony formation, cell cycle, and xenograft tumorigenesis was not involved in this study. Third, although we revealed the oncogene function of HOTTIP in GC, its probable downstream mediators are still unclear. Epithelial-to-mesenchymal transition (EMT) has been recognized as an important process that is associated with the progression and metastasis of several cancers including GC. However, the effect of HOTTIP on the EMT markers, such as E-cadherin, N-cadherin, and vimentin, has not been reported till now. Whether HOTTIP plays a role in EMT might be an interesting and important topic of future investigations.

\section{Conclusion}

In conclusion, our research confirmed elevated HOTTIP expression in GC tissues and cell lines. Our study also showed that high HOTTIP levels correlated with tumor progression and poor prognosis in GC patients. Regulation of HOTTIP expression influenced biological behaviors of GC cells. These findings suggested that HOTTIP may act as an oncogene in GC initiation and development, and would be not only a novel prognostic marker but also a potential therapeutic target for this disease.

\section{Disclosure}

The authors report no conflicts of interest in this work.

\section{References}

1. Ferlay J, Shin HR, Bray F, Forman D, Mathers C, Parkin DM. Estimates of worldwide burden of cancer in 2008: GLOBOCAN 2008. Int $J$ Cancer. 2010;127(12):2893-2917.

2. Siewert JR, Sendler A. The current management of gastric cancer. Adv Surg. 1999;33:69-93.

3. Duraes C, Almeida GM, Seruca R, Oliveira C, Carneiro F. Biomarkers for gastric cancer: prognostic, predictive or targets of therapy? Virchows Arch. 2014;464(3):367-378.

4. Fan H, Guo Z, Wang C. Combinations of gene ontology and pathway characterize and predict prognosis genes for recurrence of gastric cancer after surgery. DNA Cell Biol. 2015;34(9):579-587.

5. Liang L, Fang JY, Xu J. Gastric cancer and gene copy number variation: emerging cancer drivers for targeted therapy. Oncogene. 2015 doi:10.1038/onc.2015.209.

6. Nishida Y, Kuwata T, Nitta H, et al. A novel gene-protein assay for evaluating HER2 status in gastric cancer: simultaneous analyses of HER2 protein overexpression and gene amplification reveal intratumoral heterogeneity. Gastric Cancer. 2015;18(3):458-466.

7. Guttman M, Rinn JL. Modular regulatory principles of large non-coding RNAs. Nature. 2012;482(7385):339-346.

8. Cheetham SW, Gruhl F, Mattick JS, Dinger ME. Long noncoding RNAs and the genetics of cancer. Br J Cancer. 2013;108(12):2419-2425.

9. Mercer TR, Dinger ME, Mattick JS. Long non-coding RNAs: insights into functions. Nat Rev Genet. 2009;10(3):155-159.

10. Gibb EA, Brown CJ, Lam WL. The functional role of long non-coding RNA in human carcinomas. Mol Cancer. 2011;10:38.

11. Su S, Gao J, Wang T, Wang J, Li H, Wang Z. Long non-coding RNA BANCR regulates growth and metastasis and is associated with poor prognosis in retinoblastoma. Tumour Biol. 2015;36(9): 7205-7211.

12. Li R, Zhang L, Jia L, et al. Long non-coding RNA BANCR promotes proliferation in malignant melanoma by regulating MAPK pathway activation. PLoS One. 2014;9(6):e100893.

13. Loewen G, Jayawickramarajah J, Zhuo Y, Shan B. Functions of lncRNA HOTAIR in lung cancer. J Hematol Oncol. 2014;7(1):90.

14. Wang B, Su Y, Yang Q, et al. Overexpression of long non-coding RNA HOTAIR promotes tumor growth and metastasis in human osteosarcoma. Mol Cells. 2015;38(5):432-440.

15. Svoboda M, Slyskova J, Schneiderova M, et al. HOTAIR long noncoding RNA is a negative prognostic factor not only in primary tumors, but also in the blood of colorectal cancer patients. Carcinogenesis. 2014; 35(7):1510-1515.

16. You L, Chang D, Du HZ, Zhao YP. Genome-wide screen identifies PVT1 as a regulator of Gemcitabine sensitivity in human pancreatic cancer cells. Biochem Biophys Res Commun. 2011;407(1):1-6. 
17. Takahashi K, Yan IK, Wood J, Haga H, Patel T. Involvement of extracellular vesicle long noncoding RNA (linc-VLDLR) in tumor cell responses to chemotherapy. Mol Cancer Res. 2014;12(10):1377-1387.

18. Pickard MR, Williams GT. Regulation of apoptosis by long non-coding RNA GAS5 in breast cancer cells: implications for chemotherapy. Breast Cancer Res Treat. 2014;145(2):359-370.

19. Wang KC, Yang YW, Liu B, et al. A long noncoding RNA maintains active chromatin to coordinate homeotic gene expression. Nature. 2011; 472(7341):120-124.

20. Zhang H, Zhao L, Wang YX, Xi M, Liu SL, Luo LL. Long non-coding RNA HOTTIP is correlated with progression and prognosis in tongue squamous cell carcinoma. Tumour Biol. Epub 2015 Jun 10.

21. Deng HP, Chen L, Fan T, Zhang B, Xu Y, Geng Q. Long non-coding RNA HOTTIP promotes tumor growth and inhibits cell apoptosis in lung cancer. Cell Mol Biol. 2015;61(4):34-40.

22. Li Z, Zhao X, Zhou Y, et al. The long non-coding RNA HOTTIP promotes progression and gemcitabine resistance by regulating HOXA13 in pancreatic cancer. J Transl Med. 2015;13:84.

23. Tsang FH, Au SL, Wei L, et al. Long non-coding RNA HOTTIP is frequently up-regulated in hepatocellular carcinoma and is targeted by tumour suppressive miR-125b. Liv Int. 2015;35(5):1597-1606.
24. Li H, Yu B, Li J, et al. Overexpression of 1ncRNA H19 enhances carcinogenesis and metastasis of gastric cancer. Oncotarget. 2014;5(8): 2318-2329.

25. Zhou X, Yin C, Dang Y, Ye F, Zhang G. Identification of the long non-coding RNA H19 in plasma as a novel biomarker for diagnosis of gastric cancer. Sci Rep. 2015;5:11516.

26. Li L, Zhang L, Zhang Y, Zhou F. Increased expression of LncRNA BANCR is associated with clinical progression and poor prognosis in gastric cancer. Biomed Pharmacother. 2015;72:109-112.

27. Zhang XW, Bu P, Liu L, Zhang XZ, Li J. Overexpression of long non-coding RNA PVT1 in gastric cancer cells promotes the development of multidrug resistance. Biochem Biophys Res Commun. 2015; 462(3):227-232.

28. Cheng Y, Jutooru I, Chadalapaka G, Corton JC, Safe S. The long noncoding RNA HOTTIP enhances pancreatic cancer cell proliferation, survival and migration. Oncotarget. 2015;6(13):10840-10852.

29. Quagliata L, Matter MS, Piscuoglio S, et al. Long noncoding RNA HOTTIP/HOXA13 expression is associated with disease progression and predicts outcome in hepatocellular carcinoma patients. Hepatology. 2014;59(3):911-923.
OncoTargets and Therapy

\section{Publish your work in this journal}

OncoTargets and Therapy is an international, peer-reviewed, open access journal focusing on the pathological basis of all cancers, potential targets for therapy and treatment protocols employed to improve the management of cancer patients. The journal also focuses on the impact of management programs and new therapeutic agents and protocols on

\section{Dovepress}

patient perspectives such as quality of life, adherence and satisfaction. The manuscript management system is completely online and includes a very quick and fair peer-review system, which is all easy to use. Visit http://www.dovepress.com/testimonials.php to read real quotes from published authors. 